Article

\title{
Comparing Nutrient Removal from Membrane Filtered and Unfiltered Domestic Wastewater Using Chlorella vulgaris
}

\author{
Elyssia Mayhead, Alla Silkina ${ }^{(}$, Carole A. Llewellyn and Claudio Fuentes-Grünewald * \\ Bioscience department, Swansea University, Singleton Park, Swansea SA2 8PP, UK; \\ elyssia.mayhead@gmail.com (E.M.); a.silkina@swansea.ac.uk (A.S.); c.a.llewellyn@swansea.ac.uk (C.A.L.) \\ * Correspondence: c.fuentesgrunewald@swansea.ac.uk; Tel.: +44-1792-295446
}

Received: 28 November 2017; Accepted: 16 January 2018; Published: 19 January 2018

\begin{abstract}
The nutrient removal efficiency of Chlorella vulgaris cultivated in domestic wastewater was investigated, along with the potential to use membrane filtration as a pre-treatment tool during the wastewater treatment process. Chlorella vulgaris was batch cultivated for 12 days in a bubble column system with two different wastewater treatments. Maximum uptake of $94.18 \%$ ammonium $\left(\mathrm{NH}_{4}-\mathrm{N}\right)$ and $97.69 \%$ ortho-phosphate $\left(\mathrm{PO}_{4}-\mathrm{P}\right)$ occurred in $0.2 \mu \mathrm{m}$ membrane filtered primary wastewater. Membrane filtration enhanced the nutrient uptake performance of $C$. vulgaris by removing bacteria, protozoa, colloidal particles and suspended solids, thereby improving light availability for photosynthesis. The results of this study suggest that growing $C$. vulgaris in nutrient rich membrane filtered wastewater provides an option for domestic wastewater treatment to improve the quality of the final effluent.
\end{abstract}

Keywords: domestic wastewater; bioremediation; membrane technology; microalgae; Chlorella vulgaris; eutrophication

\section{Introduction}

The exponentially increasing human population has led to intense consumption of freshwater through domestic, agricultural and industrial uses, generating large volumes of wastewater [1]. A total of $66 \%$ of the world's population is predicted to live in urban areas by 2050 [2]; this will place increased pressure on the finite freshwater resource and requires efficient domestic wastewater management to keep up with demand, whilst mitigating the global environmental phenomenon: eutrophication [3,4]. However, there are a number of issues with wastewater treatment that need to be addressed in order to sustainably improve the quality of effluent discharged from treatment facilities. Issues include: high energy consumption, particularly in biological treatment of domestic wastewater and the use of chemicals to control high nutrient effluent levels which have economic and environmental costs [5]. Loading of bioavailable nutrients and degradable organic material into aquatic systems poses another issue due to the resulting environmental degradation of rivers, lakes and coastal water bodies [6,7]. The main objective of domestic wastewater treatment is to remove or decrease: (1) harmful levels of microbes (e.g., pathogenic coliform bacteria, protozoa, viruses and parasitic worm eggs), (2) biochemical oxygen demand (BOD), (3) pollutant levels of nutrients (e.g., nitrogen $(\mathrm{N})$ and phosphorus $(\mathrm{P})$ ), (4) heavy metals (e.g., zinc, copper, mercury, lead, aluminium) and (5) solid material $[8,9]$.

Current wastewater treatment occurs through a number of stages including pre-treatment, primary (mechanical), secondary (biological) and in some cases tertiary (chemical) treatment, as shown in Figure 1 [10]. European regulations require wastewater to be treated to at least the secondary treatment level [11]. This level of treatment ensures removal of BOD, preventing depletion 
of dissolved oxygen in receiving water bodies and resultant death of aerobic organisms such as fish. Harmful microbes are reduced to safe levels, primarily through the process of biological oxidation and adsorption $[8,12]$.

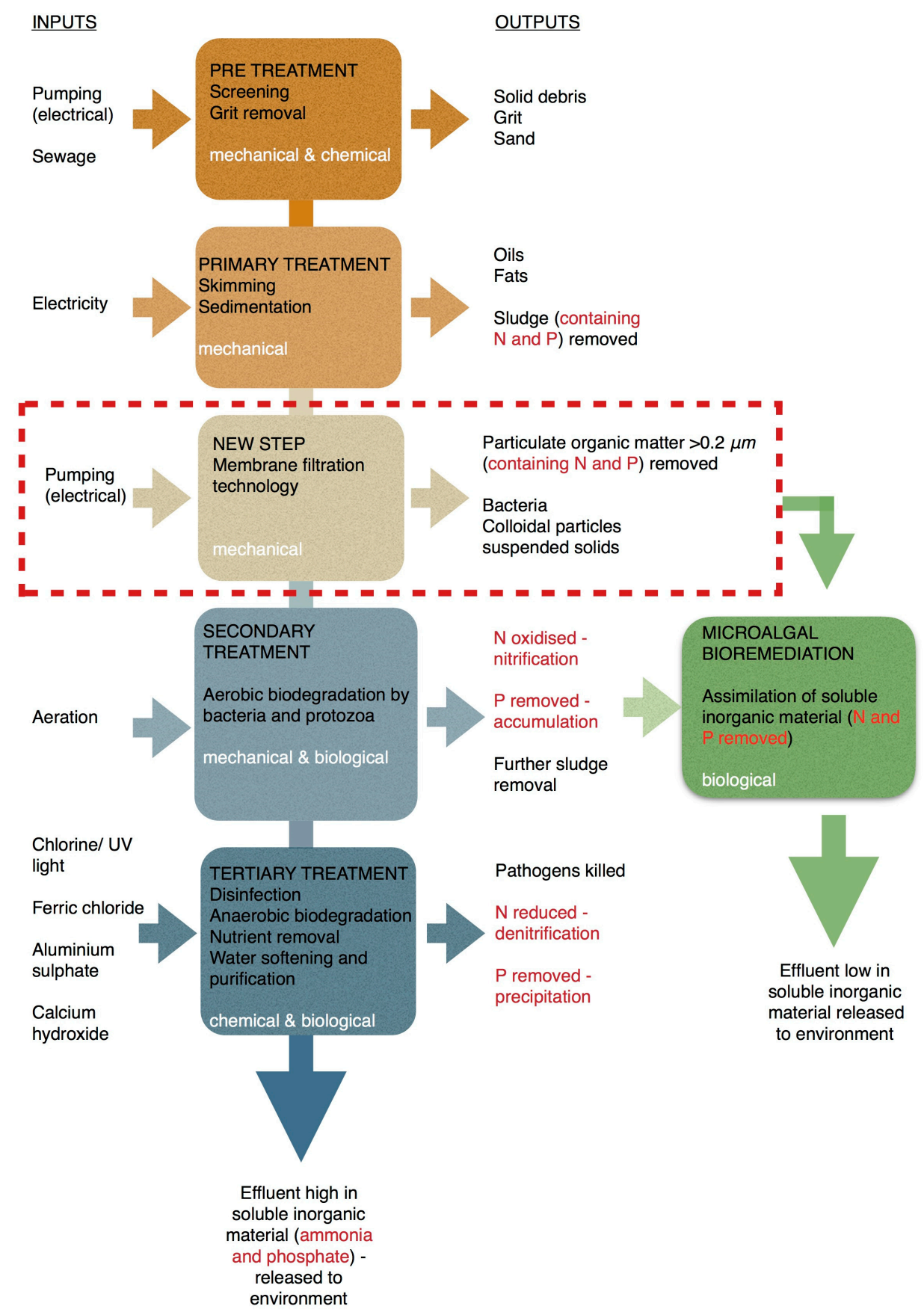

Figure 1. Generalised wastewater treatment process and proposed technology. Figure adapted from Carlisle [13].

Despite the process of primary and secondary wastewater treatment, wastewater effluent can remain loaded with soluble inorganic pollutants such as $\mathrm{NH}_{4}-\mathrm{N}, \mathrm{PO}_{4}-\mathrm{P}$ and heavy metals due to the inability of bacteria and protozoa, the predominant microbial community, to assimilate them [12]. Therefore, wastewater treatment facilities that discharge effluent into sensitive areas (as classified by the Water Framework Directive (WFD)) operate tertiary treatment as a means 
of removing these soluble compounds $[8,14]$. However, the complete tertiary process has been estimated to be four times more expensive than primary treatment and requires toxic chemicals [15]. These challenges present the potential for more innovative approaches to wastewater treatment. One innovative approach for removal of soluble inorganic pollutants from domestic wastewater is through bioremediation, using naturally occurring photosynthetic microalgae $[8,16,17]$, a process otherwise known as phycoremediation. Microalgae are superior to other microorganisms in bioremediation of wastewater as they are able to acquire inorganic compounds far more readily than bacteria. Microalgae also have reduced health and safety risks associated with accidental release to the environment, as they are relatively non-pathogenic [18]. Phycoremediation of wastewater has the potential to reduce the use of harmful chemicals such as aluminium sulphate and ferric chloride, currently used to remove soluble phosphate $\left(\mathrm{PO}_{4}-\mathrm{P}\right)$ [19]. However, optimum culture conditions are essential for effective phycoremediation. Therefore, low energy physical treatment such as filtration by pressure driven membrane technology has been proposed and can offer a sustainable low-cost solution. Membrane Technology (MT) is scalable with numerous arrangements and alternatives and easy to incorporate and integrate into waste treatment processes. It offers low operational cost (OPEX) compared to other competing technologies since there is no phase change required and minimal or no use of chemical additives $[20,21]$. Using this technology, waste can be recycled back to the production systems substituting for newly manufactured materials.

In this study, MT has been applied to the domestic wastewater treatment process in order to improve the culture conditions for microalgal bioremediation. Through improving the culture conditions and subsequent nutrient removal efficiency of microalgae at the tertiary treatment stage, MT has the potential to reduce the cost of the whole domestic wastewater treatment process. MT has been used in water purification and wastewater treatment since the late 1960's. Microfiltration, in particular, can be used to remove unicellular bacteria and protozoa that feed on, compete with or inhibit microalgae [22]. Membrane filtration is therefore being considered as an alternative to UV radiation in removing bacteria and purifying water in Korea [23]. Colloidal particles and suspended solids are also removed by microfiltration, and studies have revealed that removal of these components of waste streams increases light utilization in photosynthesis, which improves microalgal growth and subsequent inorganic nutrient removal [21,23]. Previous research [20-24] has demonstrated that membrane filtration integrated in the wastewater treatment cycle has been proposed and successfully applied for converting waste sludge into a particle free, nutrient rich fluid and a nutrient depleted solid stream. The solid fraction is a retentate stream with reduced nutrient content that can be applied to land as an organic fertilizer, while the soluble organic matter (ammonia and phosphate) can be concentrated and formulated into more useful materials and so valorising this route for the waste. The soluble fraction is a source of water and nutrients used as growth media for cultivation of algae, microbes and plants. Microalgal cultivation uses nutrients such as Nitrogen (ammonium) and Phosphorus (ortho-phosphate) for the growth of valuable algal biomass. The remediation process is very quick and represents environmentally friendly scalable technology, as does MT. These two technologically low cost processes could be applied together for successful waste remediation.

The aims of this study were to:

(1) Evaluate the application of microalgae to current wastewater treatment with a focus on improving the quality of final effluent.

(2) Assess the use of membrane technology to be included as a part of the wastewater treatment process.

\section{Materials and Methods}

\subsection{Wastewater Collection}

Primary domestic wastewater $(\mathrm{ww})$ was obtained from a Welsh Water treatment facility in Southgate, Swansea $\left(51^{\circ} 34^{\prime} 12^{\prime \prime} \mathrm{N}, 4^{\circ} 05^{\prime} 01^{\prime \prime} \mathrm{W}\right)$. At this facility, sewage undergoes primary and 
secondary treatment. A thirty-litre aliquot of primary wastewater was a grab sample from the settling tank prior to biological filtration [25]. Samples were transported to the Centre for Sustainable Aquatic Research located in Swansea University, South Wales, and stored at $3{ }^{\circ} \mathrm{C}$ for one week until sterilisation.

\subsection{Pre-Treatments and Characteristics of Wastewater}

The wastewater was sterilised (10 L at a time) following Li et al. [26] and Sharma et al. [27] using an autoclave oven at $121^{\circ} \mathrm{C}$ for $20 \mathrm{~min}$ (Rodwell model 56, Rodwell, Basildon, UK). The pre-treatment of wastewater used in the filtered Treatment 1 underwent microfiltration using a membrane filtration rig with a $0.2 \mu \mathrm{m}$ pore size hollow fiber (polysulfone) tangential flow cartridge (GE healthcare); the active surface area in the cartridge was $0.9 \mathrm{~m}^{2}$, and the average cross flow was $778 \mathrm{~L} \mathrm{~h}^{-1}$. The nutrient concentration $\left(\mathrm{NH}_{4}-\mathrm{N} ; \mathrm{PO}_{4}-\mathrm{P}\right)$ of the sampled wastewater is shown in Table 1.

Table 1. Nutrient concentration of autoclaved primary and secondary domestic wastewater from the Southgate facility.

\begin{tabular}{ccc}
\hline Nutrients & \multicolumn{2}{c}{ Concentration $\left(\mathbf{m g ~ L}^{-\mathbf{1}}\right)$} \\
\hline & Primary & Secondary (effluent) \\
$\mathrm{NH}_{4}-\mathrm{N}$ & $104.51 \pm 0.455$ & $<5$ \\
$\mathrm{PO}_{4}-\mathrm{P}$ & $23.65 \pm 0.087$ & $15.41 \pm 0.066$ \\
& Reference to a level below $5 \mathrm{mg} \mathrm{L}^{-1}$, as this is the detection limit for $\mathrm{NH}_{4}-\mathrm{N}$.
\end{tabular}

\subsection{Experimental Layout}

\subsubsection{Algal Species and Culture Conditions}

The unicellular green microalgae species Chlorella vulgaris Beijerinck (1890) strain CCAP 211/11R was cultivated under a controlled temperature of $20 \pm 1{ }^{\circ} \mathrm{C}$ using four conditions carried out in triplicate $[26,28,29]$. The three conditions were:

a (Control) F2P media in freshwater

b (T1) $100 \%$ primary filtered ww

c (T2) $100 \%$ primary unfiltered ww

The F2P medium provides known optimal culture conditions for microalgal growth and nutrient uptake. Therefore, F2P was used as a control in this experiment to enable comparison with the results of wastewater cultivation. T1 was used for comparison with T2 to investigate the effect of membrane filtration on microalgal growth and nutrient uptake in primary ww.

\subsubsection{Bubble Column System}

Chlorella vulgaris was cultivated autotrophically by batch culture in sterilised bubble columns of $0.3 \mathrm{~cm}$ thick transparent acrylic (height: $120 \mathrm{~cm}$, internal diameter: $10.5 \mathrm{~cm}$ ). The study was split into two experiments, each of which spanned 12 days, involving six columns in the first experiment and 3 columns in the second experiment (Figure 2). 
(a)

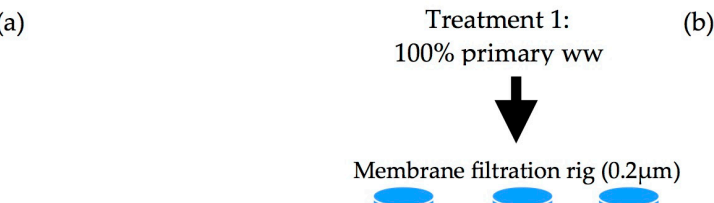

(b)
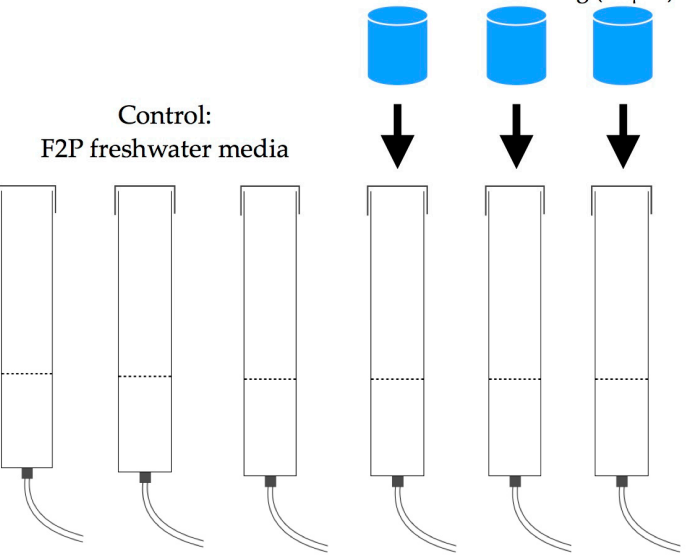

Treatment 3:

$100 \%$ primary unfiltered ww
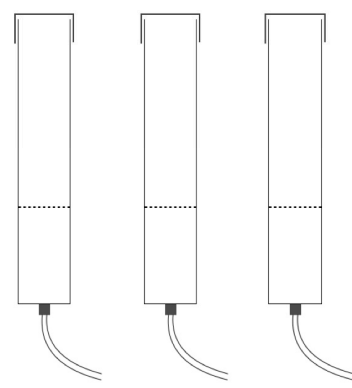

Figure 2. Bubble columns system for Chlorella vulgaris cultures (a) Experiment one, (b) Experiment two.

\subsubsection{Aeration}

Filter sterilized ambient air $\left(0.039 \% \mathrm{CO}_{2}\right)$ was fed into the bottom of the columns supplied by a pressurized tank and controlled by a valve (Part e. Figure 3). The flow rate was standardized to $0.5 \mathrm{~L} \mathrm{~min}^{-1}$ across columns [28,30]. Aeration with $\mathrm{CO}_{2}$ agitated the culture [31]; this was maintained throughout the 12-day period.

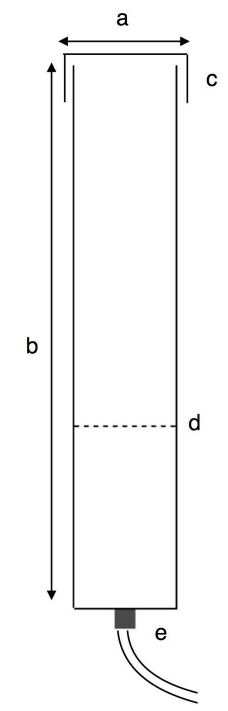

Figure 3. Bubble column apparatus. (a) Column diameter $10.8 \mathrm{~cm}$; (b) column height $120 \mathrm{~cm}$, (c) lid, (d) culture level $\left(4 \mathrm{~L}=47 \mathrm{~cm}\right.$ gas-free liquid height, $3.2 \mathrm{~L}=36 \mathrm{~cm}$ gas-free liquid height), (e) $\mathrm{CO}_{2}$ control valve.

\subsubsection{Daily Illumination}

The columns were illuminated over an $18 \mathrm{~h}$ photoperiod and $6 \mathrm{hr}$ dark period each day. During the photoperiod, white light was provided by tubular fluorescent lamps producing an average of $177 \mu \mathrm{mol} \mathrm{m}{ }^{-2} \mathrm{~s}^{-1}$ photons (58W Osram, LUMILUX T8, Münich, Germany). Photon flux density 
was established by taking the mean of three points along columns $(n=6)$ using a PAR irradiance sensor and Universal Light Meter-500 (WALZ, Effeltrich, Germany).

\subsubsection{Experimental Design}

\section{Experiment $1-$ Control and Treatment 1 (C \& T1)}

Bubble columns had a working volume of $4 \mathrm{~L}$ and gas-free liquid height of $47 \mathrm{~cm}$ (Figure 2a). The control consisted of sterilized freshwater and $20 \mathrm{~mL}$ cell-hi F2P media (Varicon Aqua Solutions Ltd., Worcestershire, UK) passed through a syringe filter of $0.45 \mu \mathrm{m}$ (Minisart ${ }^{\circledR}$, Sartorius, Surrey, UK) for sterilization. T1 consisted of $100 \%$ membrane filtered primary wastewater. The initial inoculum concentration of $C$. vulgaris taken from a $20 \mathrm{~L}$ culture stock was $3.4 \times 10^{6} \pm 151,905 \mathrm{cell} \mathrm{mL}^{-1}$.

Experiment 2-Treatment 2 (T2)

Bubble columns had a working volume of $3.2 \mathrm{~L}$. The gas-free liquid height was $36 \mathrm{~cm}$ (Figure 2b). $\mathrm{T} 2$ consisted of $100 \%$ unfiltered primary wastewater. The initial inoculum concentration taken from the same $20 \mathrm{~L}$ culture stock was $1.4 \times 10^{6} \pm 283,976$ cell mL ${ }^{-1}$, this follows the method of Cho et al. [23].

\subsection{Sampling}

Samples $(n=7)$ were taken at the same time each day $( \pm 2 h)$ over a period of 12 days. These were taken on consecutive days for the first three samples in both experiments; further samples were taken within a maximum of $72 \mathrm{~h}$ of each other. Samples from T2 (unfiltered wastewater) were filtered prior to cell count measurement using a $50 \mu \mathrm{m}$ mesh, preventing solid particles $>50 \mu \mathrm{m}$ from affecting growth measurements.

\subsection{Growth Determination}

The growth of $C$. vulgaris was monitored by optical density (OD), cell count (CC) and dry weight (DW). Prior to all measurements, samples were mixed for $30 \mathrm{~s}$ using a vortex (VWR Vortex Genie ${ }^{\circledR}$, VWR, Lutterworth, UK) to ensure homogeneity. OD was carried out using a spectrophotometer $\left(\mathrm{VWR}^{\circledR}\right.$, version $1200, \mathrm{VWR}$, Lutterworth, UK) at $750 \mathrm{~nm}$, as this wavelength reduces interference by pigments [32]. To reduce error in measurements above 1.0 absorbance, the sample was diluted by deionised water and the resultant absorption multiplied by the dilution factor. CC was conducted using a phase contrast microscope (Olympus $\mathrm{CH}$ series, Olympus, Hamburg, Germany) at $\times 40$ magnification and Neubauer improved haemocytometer following Whitton et al. [33]. Dense cultures (above 100 cells per large square) were diluted with deionised water before counting to reduce human error and to improve accuracy. The centre square of the haemocytometer was used for CC.

DW was conducted using a Millipore Sterifil ${ }^{\circledR}$ filtration system (Merck, Darmstad, Germany) and $0.42 \mu \mathrm{m}$ glass microfiber filter disks (Whatman ${ }^{\circledR}$ GF/C, GE Healthcare, Maidstone, UK). Filter disks were weighed (KERN ABS80-4N, Kern, Balingen, Germany) prior to filtration. A vacuum pump (Charles Austen model B100, Charles Austen, Surrey, UK) was used to filter a known volume (10 or $20 \mathrm{~mL}$ ) of culture sample through the filter disk. The resultant filtered water $(10 \mathrm{~mL})$ was frozen at $-21^{\circ} \mathrm{C}$ for later nutrient analysis before washing with $20 \mathrm{~mL}$ deionised water, leaving the biomass on the disk. Disks were dried at $80^{\circ} \mathrm{C}$ for a minimum of $24 \mathrm{~h}$ before taking the final weight of the filter and culture.

Equation (1) was used to calculate the biomass production as the dry weight of each culture sample:

$$
\text { Dry weight }\left(\mathrm{g} \mathrm{L}^{-1}\right)=\frac{\text { Culture }(\mathrm{g}) \times 1000}{\text { filtered volume }(\mathrm{mL})}
$$

Equation (2) represents the linear relationship between optical density $(750 \mathrm{~nm})$ and dry weight $\left(\mathrm{mg} \mathrm{L}^{-1}\right)$ :

$$
\text { Dry weight }\left(\mathrm{mg} \mathrm{L}^{-1}\right)=0.275 \times O D_{750}-0.0128, R^{2}=0.9856
$$


Specific growth rate, $\mu\left(\mathrm{d}^{-1}\right)$, was determined using Equation (3):

$$
\mu\left(\mathrm{d}^{-1}\right)=\frac{\ln \left[\frac{x_{2}}{x_{1}}\right]}{t_{2}-t_{1}}
$$

where $x_{1}$ and $x_{2}$ are defined as optical density $(750 \mathrm{~nm})$ at time $t_{1}$ and $t_{2}$, respectively.

\subsection{Nutrient Analysis and $p H$ Monitoring}

Nutrient analysis was conducted for all four conditions at six points during the growth of C. vulgaris. For consistent measurement of the depletion of soluble inorganic ammonium $\left(\mathrm{NH}_{4}-\mathrm{N}\right)$ and ortho-phosphate $\left(\mathrm{PO}_{4}-\mathrm{P}\right)$, photometric analysis was performed. Commercially available colorimetric assay kits (Machery-Nagel NANOCOLOR ${ }^{\circledR}$ ammonium 100 and ortho-phosphate, Machery-Nagel, Düren, Germany) were used for analysis of blue indophenol $(585 \mathrm{~nm})$ and phosphomolybdenum blue $(690 \mathrm{~nm})$, respectively, using a VWR ${ }^{\circledR} \mathrm{V}-1200$ spectrophotometer.

Changes in $\mathrm{pH}$ were monitored using the Aqua Digital ${ }^{\mathrm{TM}} \mathrm{pH}$ controller (version 201, Aqua Digital, Southhampton, UK). The probe was taken out of the $\mathrm{pH} 7$ buffer solution, and excess solution was removed before placing the probe in each sample for measurement. Between measurements, the probe was cleaned with deionised water, excess was removed, and the probe was placed back into the buffer solution.

\subsection{Statistical Analysis}

All data from bubble columns of both experiments in the study were tested for normality using the Kolmogorov-Smirnov goodness-of-fit test. The assumptions were satisfied, resulting in the use of nested/hierarchical ANOVA where condition was nested within day, which was nested within experiment. Statistical analysis was conducted to determine the significance of the difference between conditions at $p<0.05$ level, using Minitab 17 (Minitab, Coventry, UK).

\section{Results}

\subsection{Algal Growth}

In the first experiment, C. vulgaris underwent a stationary phase beyond day 9. In the Control and $\mathrm{T} 1$, this stationary phase is presented by a decline in optical density beyond day 9 in Figure $4 a, b$. In the second experiment, $C$. vulgaris continued growing beyond day 9 in T2. All conditions experienced a higher initial growth rate $\left(\mu_{1}\right)$ between day 0 and day 2 than the overall growth rate $\left(\mu_{2}\right)$ between day 0 and day 9.

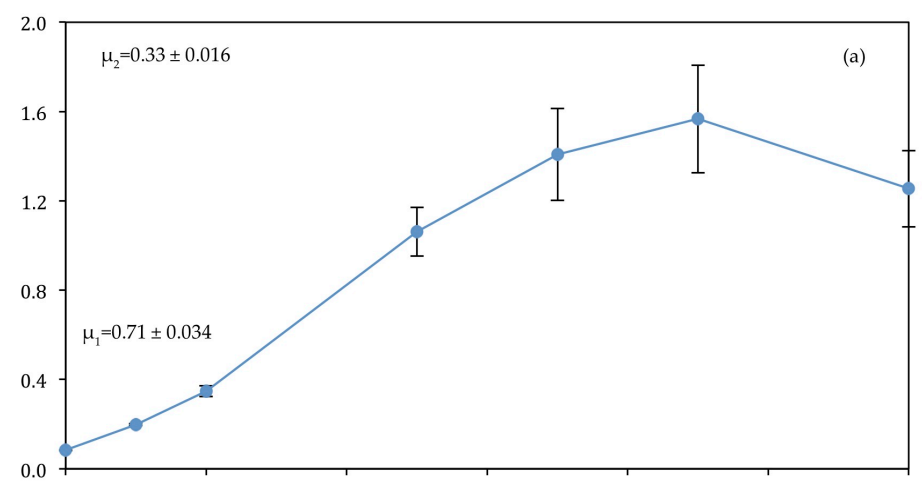

Figure 4. Cont. 

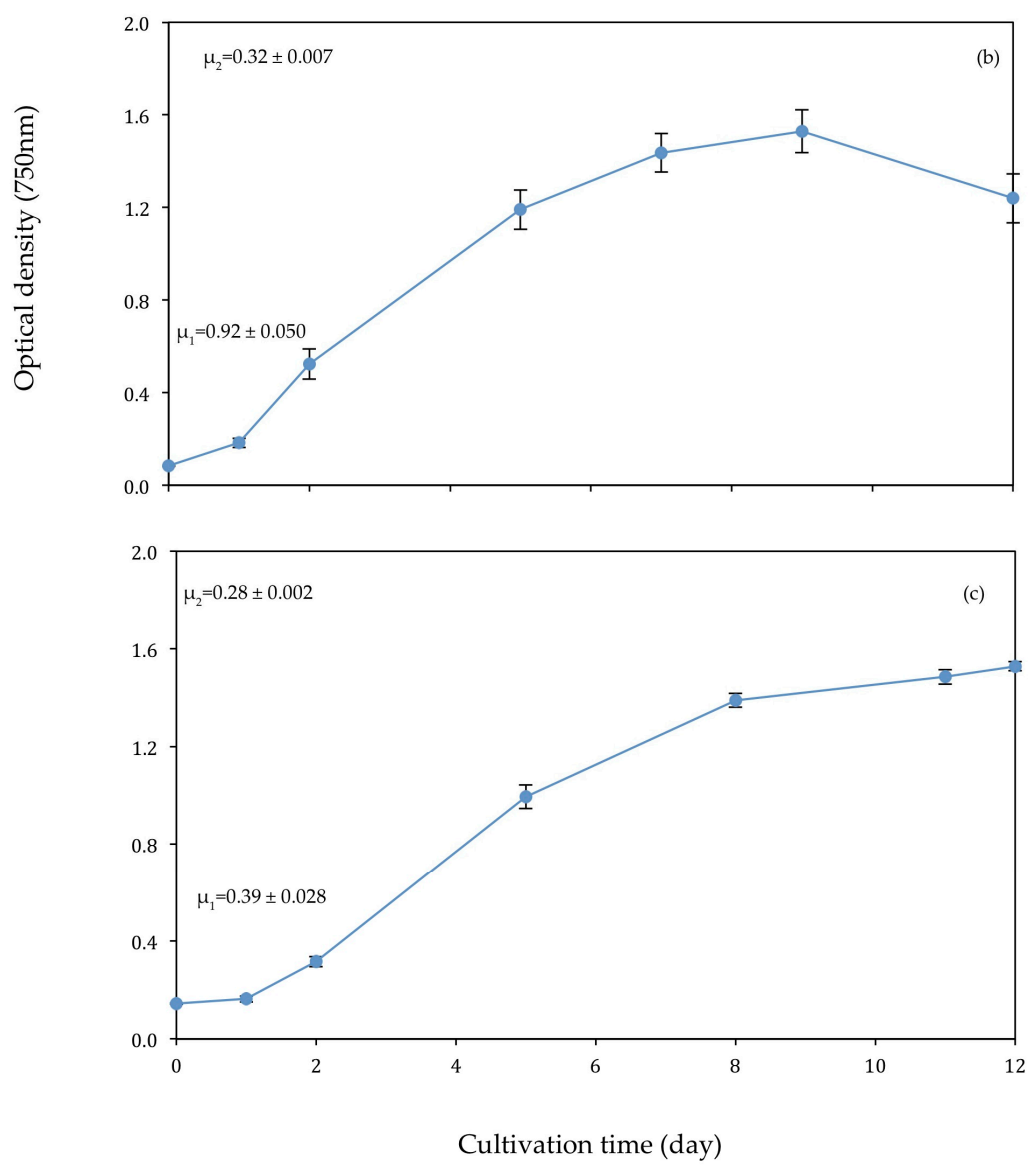

Figure 4. (a) Control (b) T1 (c) T2. Growth curves for C. vulgaris. Bars represent standard deviation (SD). Absence of a bar indicates negligible SD. $\mu_{1}=$ initial growth rate $\pm 1 \mathrm{SD}, \mu_{2}=$ overall growth rate $\pm 1 \mathrm{SD}$. Statistical analysis of the difference in specific growth rates across conditions could not be conducted; however, values for optical density differ significantly between conditions when analysed by nested ANOVA $(f=30.515, p=0.005)$, suggesting a significant difference in growth across conditions.

T1 experienced the highest initial growth rate $\left(0.920 \pm 0.050 \mathrm{~d}^{-1}\right)$ (Figure 4). However, the control had the highest overall growth rate of $0.330 \pm 0.019 \mathrm{~d}^{-1}$. The slopes of the curves suggest that unfiltered wastewater is least suitable for biomass production as this generated the lowest initial and overall growth rates $\left(0.391 \pm 0.028 \mathrm{~d}^{-1}, 0.283 \pm 0.002 \mathrm{~d}^{-1}\right.$, respectively). However, the results of biomass production (Figure 5) do not support this suggestion, as T2 had the highest biomass production of all treatments $\left(0.527 \pm 0.104 \mathrm{~g} \mathrm{~L}^{-1}\right)$. The high initial growth rate of T1 coincides with high initial levels of $\mathrm{NH}_{4}-\mathrm{N}\left(85.84 \mathrm{mg} \mathrm{L}^{-1}\right)$ and $\mathrm{PO}_{4}-\mathrm{P}\left(13.54 \pm 0.16 \mathrm{mg} \mathrm{L}^{-1}\right)$, resulting in an N:P ratio of 7.5:1.0. 

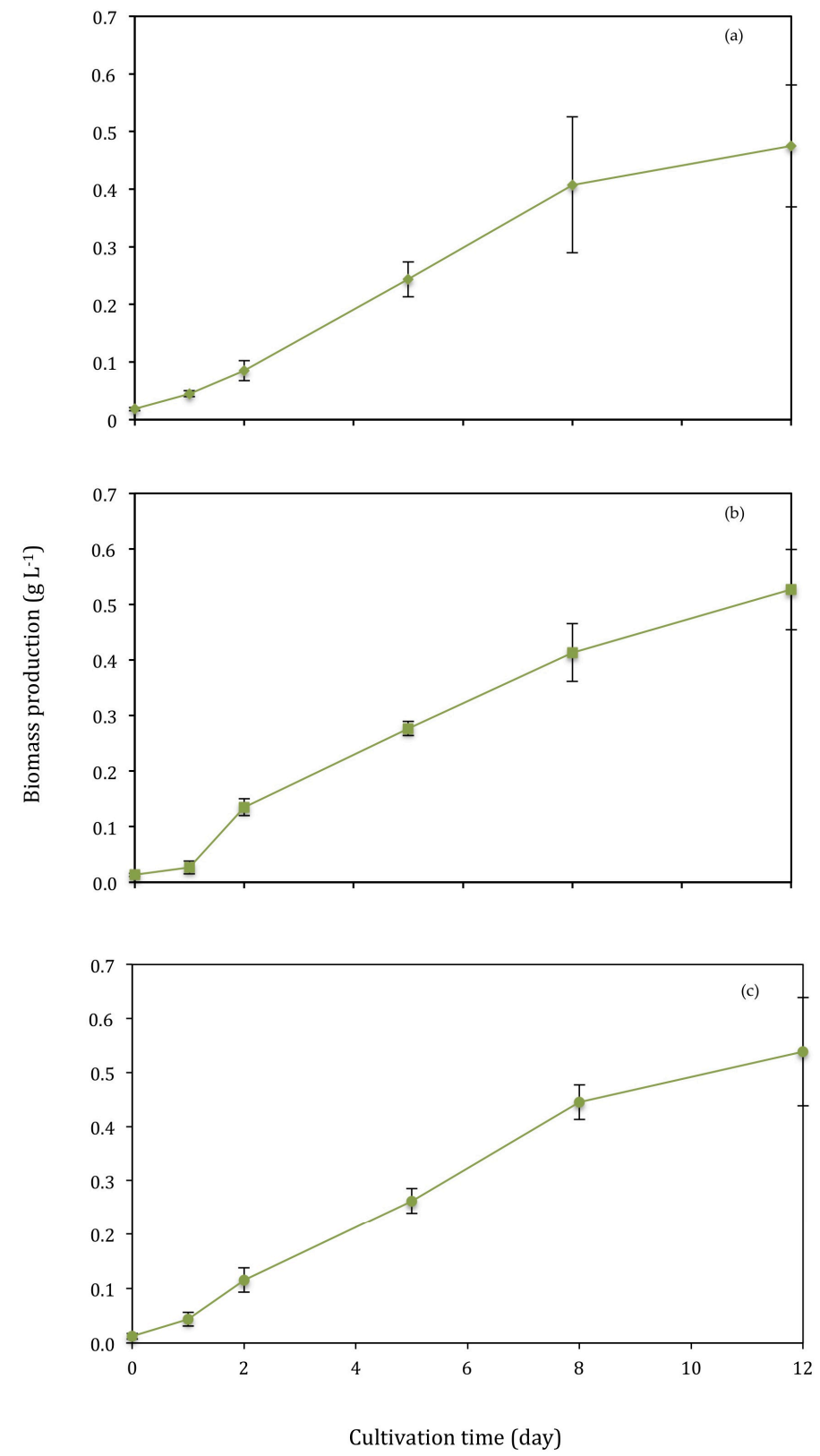

Figure 5. (a) Control (b) $\mathrm{T} 1$ (c) T2. Biomass production, determined by dry weight $\left(\mathrm{g} \mathrm{L}^{-1}\right)$. Bars represent SD.

\subsection{Biomass Production}

T2 had the highest biomass production of all treatments after accounting for the presence of unfiltered particles $<50 \mu \mathrm{m}$ within the samples (Figure 5). Unfiltered particles were accounted for by measuring the dry weight of a sample of unfiltered primary wastewater prior to inoculation with Chlorella vulgaris. The average dry weight of unfiltered particles was $0.028 \pm 0.007 \mathrm{~g} \mathrm{~L}^{-1}$, which was subtracted from the dry weight measurements for $\mathrm{T} 2$ on each of the sample days during the 12-day cultivation period.

Dry weight $\left(\mathrm{g} \mathrm{L}^{-1}\right)$ differed significantly $(f=212.597, p=0.005)$ between days, as expected, but not between conditions when analysed by nested ANOVA. Biomass production increased throughout the cultivation period under all conditions (Figure 5). Biomass production of the 12-day cultivation period was $0.457 \pm 0.103 \mathrm{~g} \mathrm{~L}^{-1}, 0.513 \pm 0.070 \mathrm{~g} \mathrm{~L}^{-1}$ and $0.527 \pm 0.104 \mathrm{~g} \mathrm{~L}^{-1}$ in the control, $\mathrm{T} 1$ and 
T2, respectively. The F2P media control had a biomass productivity of $0.190 \pm 0.048 \mathrm{~g} \mathrm{~L}^{-1} \mathrm{~d}^{-1}$. The average biomass productivity of $\mathrm{T} 1$ and $\mathrm{T} 2$ was $0.164 \pm 0.020 \mathrm{~g} \mathrm{~L}^{-1} \mathrm{~d}^{-1}$.

\subsection{Bioremediation of Nutrients from Wastewater}

$\mathrm{NH}_{4}-\mathrm{N}$ and $\mathrm{PO}_{4}-\mathrm{P}$ concentrations in all of the different wastewater compositions decreased over the cultivation period (Table 2, Figures 6 and 7). There are no comparable measurements for levels of nutrients in the Control because F2P media is composed mainly of nitrate $\left(\mathrm{NO}_{3}{ }^{-}\right)$and chemically bound phosphate $\left(\mathrm{H}_{2} \mathrm{PO}_{4}^{-}\right)$. T2 (unfiltered primary wastewater) consisted of a higher initial level of $\mathrm{NH}_{4}-\mathrm{N}$ and $\mathrm{PO}^{4}-\mathrm{P}$ compared with $\mathrm{T} 1$ (filtered primary wastewater). $\mathrm{T} 1$ had the highest $\mathrm{N}: \mathrm{P}$ ratio. Removal of $\mathrm{NH}_{4}-\mathrm{N}$ was most efficient in $\mathrm{T} 2(95.22 \%)$, whereas removal of $\mathrm{PO}_{4}-\mathrm{P}$ was most efficient in $\mathrm{T} 1(97.69 \%)$. Removal percentage was used to determine removal efficiency because large variations occurred in the initial concentration of $\mathrm{NH}_{4}-\mathrm{N}$ and $\mathrm{PO}_{4}-\mathrm{P}$ across conditions.

Table 2. Characteristics of growth media before (initial) and after (final) the 12-day growth period of C. vulgaris.

\begin{tabular}{ccccc}
\hline \multirow{2}{*}{ Initial } & & Control & Treatment 1 & Treatment 2 \\
\cline { 2 - 5 } & $\mathrm{N}: \mathrm{P}$ & $2.4: 1.0$ & $7.5: 1.0$ & $4.4: 1.0$ \\
\cline { 2 - 5 } & $\mathrm{NH}_{4}-\mathrm{N}\left(\mathrm{mg} \mathrm{L}^{-1}\right)$ & $5^{1}$ & 85.84 & 104.51 \\
& $\mathrm{PO}_{4}-\mathrm{P}\left(\mathrm{mg} \mathrm{L}^{-1}\right)$ & 2.47 & 13.54 & 23.65 \\
\hline \multirow{2}{*}{ Final } & $\mathrm{NH}_{4}-\mathrm{N}\left(\mathrm{mg} \mathrm{L}^{-1}\right)$ & $5^{1}$ & $5^{1}$ & $5^{1}$ \\
& $\mathrm{PO}_{4}-\mathrm{P}\left(\mathrm{mg} \mathrm{L}^{-1}\right)$ & 0.256 & 0.313 & 0.796 \\
\hline \multirow{2}{*}{$\%$ removed } & $\mathrm{NH}_{4}-\mathrm{N}$ & $\mathrm{NA}$ & $94.18 \%$ & $95.22 \%$ \\
& $\mathrm{PO}_{4}-\mathrm{P}$ & $89.64 \%$ & $97.69 \%$ & $96.63 \%$ \\
\hline
\end{tabular}

${ }^{1}$ Reference to a level at or below $5 \mathrm{mg} \mathrm{L}^{-1}$, as this is the detection limit for $\mathrm{NH}_{4}-\mathrm{N}$.
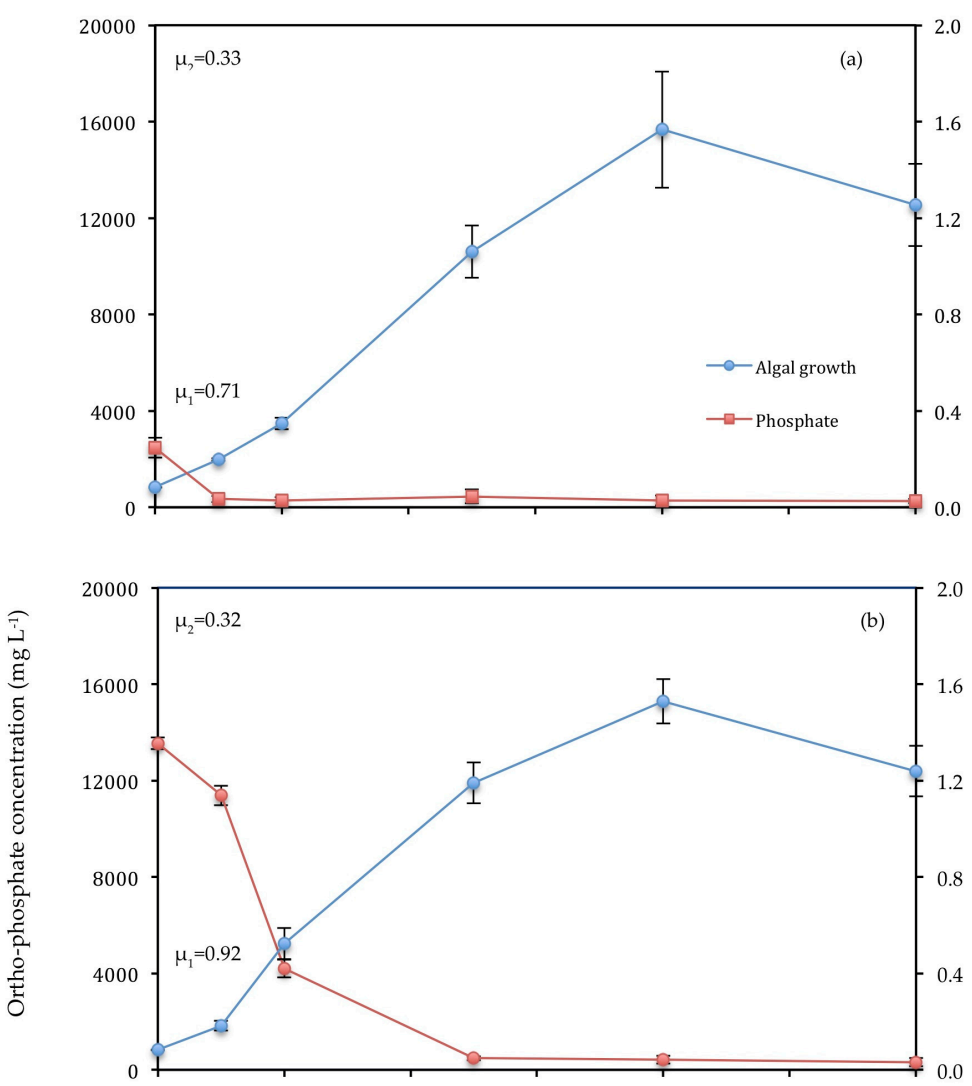

Figure 6. Cont. 


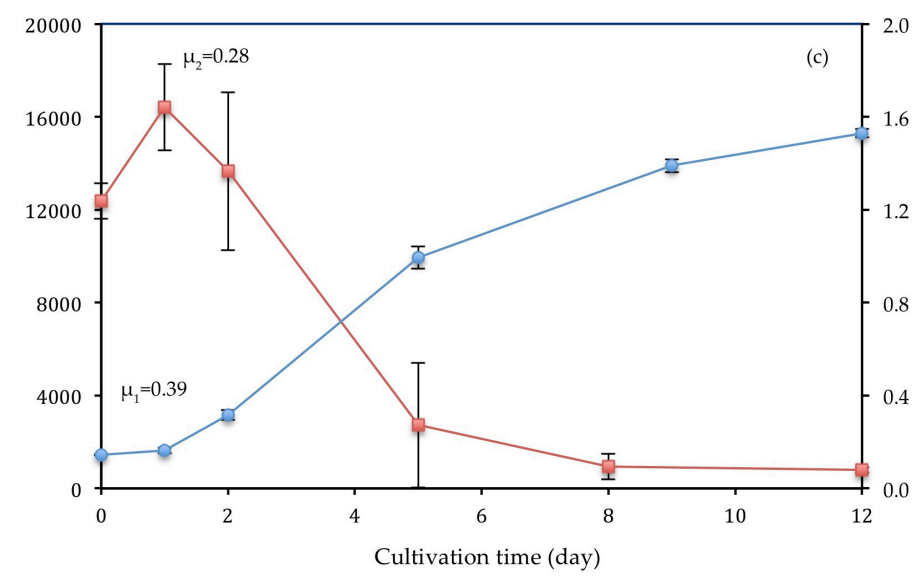

Figure 6. (a) Control (b) T1 (c) T2. Optical density of C. vulgaris and depletion of $\mathrm{PO}_{4}-\mathrm{P}\left(\mathrm{mg} \mathrm{L}^{-1}\right)$. Bars represent SD. Absence of a bar indicates negligible SD.
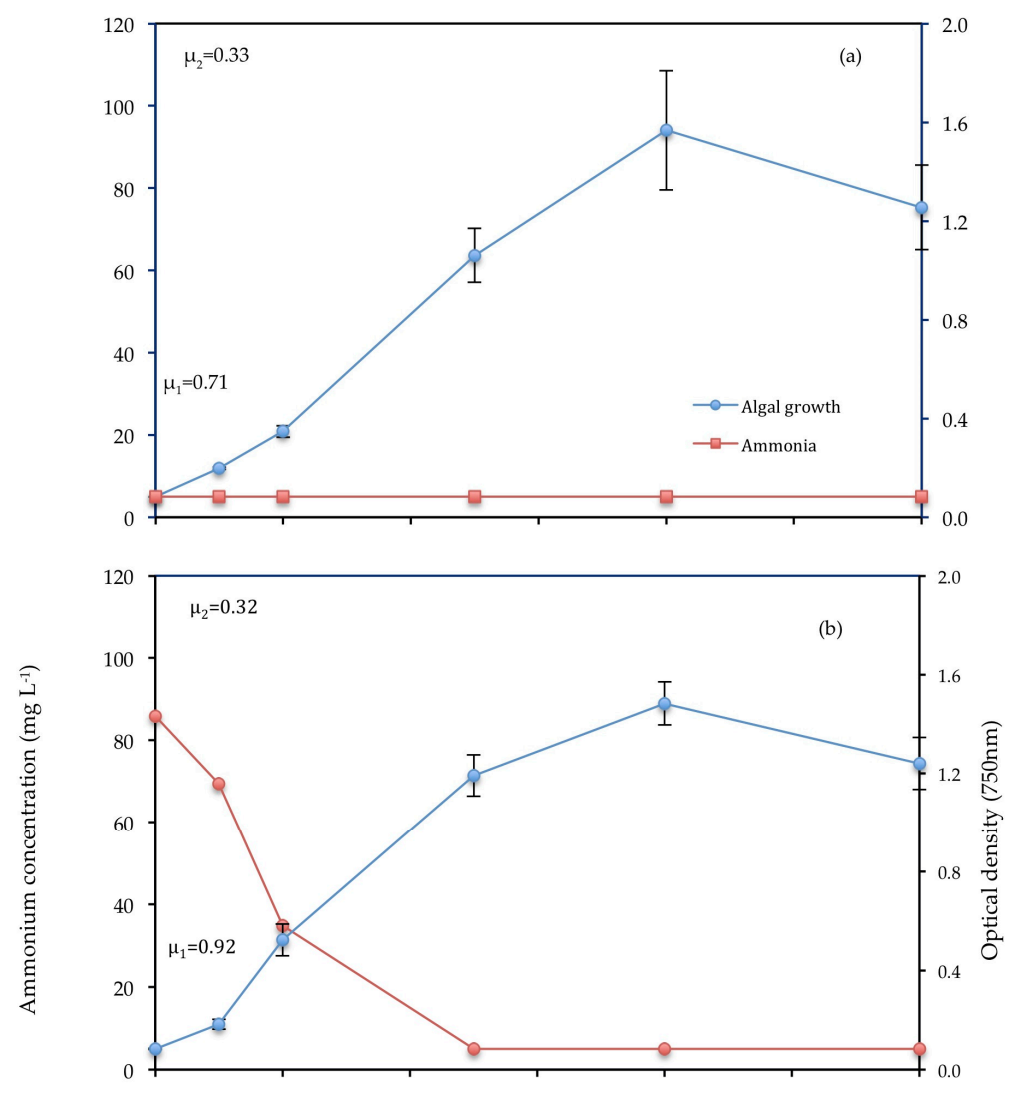

Figure 7. Cont. 


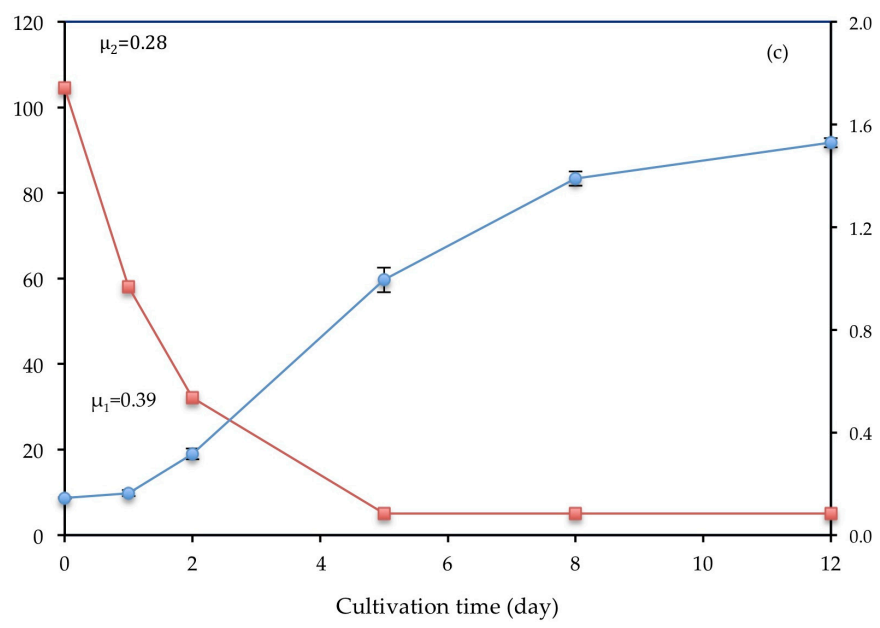

Figure 7. (a) Control (b) T1 (c) T2. Optical density of C. vulgaris and depletion of $\mathrm{NH}_{4}-\mathrm{N}\left(\mathrm{mg} \mathrm{L}^{-1}\right)$. Bars represent $\mathrm{SD}$ for optical density.

\subsubsection{Ortho-Phosphate}

When $\mathrm{PO}_{4}-\mathrm{P}$ was depleted below $0.42 \mathrm{mg} \mathrm{L}^{-1}$ in the Control (Figure 6a) and T1 (Figure 6b), algae ceased growth and entered the death phase at 8-12 days. However, $\mathrm{PO}_{4}-\mathrm{P}$ levels did not fall below this point at any stage of growth in T2 (Figure 6c). Figure $6 \mathrm{c}$ shows a peak in $\mathrm{PO}_{4}-\mathrm{P}$ on day 1 . This is likely to be due to an error in nutrient analysis as no such peak is observed in previous Figure $6 \mathrm{a}, \mathrm{b}$. Analysis by nested ANOVA revealed significant difference $(p<0.05)$ between the means of $\mathrm{PO}_{4}-\mathrm{P}$ of different conditions. T1 (filtered primary wastewater) underwent a significant decrease $(f=3.322$, $p=0.003$ ) in $\mathrm{PO}_{4}-\mathrm{P}$ from day 1 to day 2 that did not occur in $\mathrm{T} 2$ (unfiltered primary wastewater). $\mathrm{PO}_{4}-\mathrm{P}$ decreased significantly $(f=3.322, p=0.003)$ between days 0 and 5 in Treatments 1 and 2, suggesting that uptake led to rapid growth of $C$. vulgaris.

\subsubsection{Ammonium}

$\mathrm{NH}_{4}-\mathrm{N}$ was depleted to $5 \mathrm{mg} \mathrm{L}^{-1}$ by day 5 in Treatments 1 and 2 . Further depletion below this concentration was not detected by nutrient analysis as presented by the consistent low level across conditions from day 5 onwards. There was a decline in $\mathrm{NH}_{4}-\mathrm{N}$ in Treatments 1 and 2 between days 0 and 5 as the optical density of $C$. vulgaris increases. The level of $\mathrm{NH}_{4}-\mathrm{N}$ in the control was too low $\left(<5 \mathrm{mg} \mathrm{L}^{-1}\right)$ for detection.

\subsection{Comparison of the Results of Bioremediation to Current Wastewater Treatment}

The standards set by the EC for nutrient loading to aquatic systems have been used to classify the quality of wastewater after bioremediation along with the quality of final effluent produced by the Welsh Water treatment facility at Southgate, Swansea. The results in Table 3 show that bioremediation by $C$. vulgaris produces effluent with a higher classification (moderate-poor) for discharge into rivers.

Table 3. Classification of the quality of wastewater following bioremediation by C. vulgaris compared to current wastewater treatment.

\begin{tabular}{|c|c|c|c|c|}
\hline $\begin{array}{c}\text { Measure of } \\
\text { Effluent Quality }\end{array}$ & $\begin{array}{c}\text { Nutrient/Discharge } \\
\text { Area }\end{array}$ & Treatment 1 & Treatment 2 & $\begin{array}{c}\text { Current ww } \\
\text { Treatment (Table 1) }\end{array}$ \\
\hline \multirow{2}{*}{ Final level } & $\mathrm{NH}_{4}-\mathrm{N} \mathrm{mg} \mathrm{L}^{-1}$ & $<5$ & $<5$ & $<5$ \\
\hline & $\mathrm{PO}_{4}-\mathrm{P} \mathrm{mg} \mathrm{L}^{-1}$ & 0.313 & 0.796 & 15.41 \\
\hline \multirow{3}{*}{ Classification } & Rivers & Moderate-Poor & Moderate-Poor & Poor \\
\hline & Coastal & Poor & Poor & Poor \\
\hline & Lakes & $<$ Good & $<$ Good & $<$ Good \\
\hline
\end{tabular}




\section{Discussion}

This study used a common unicellular freshwater species of green microalgae, C. vulgaris (Chlorophyta), as it is robust to a wide range of nutrient loading and temperatures but most importantly because of the species' reported efficiency as a wastewater treatment agent [34-36]. C. vulgaris has been used in a variety of waters from textile to fish processing wastewater [37-39] where it has exhibited high ammonium $\left(\mathrm{NH}_{4}-\mathrm{N}\right)$ and phosphate $\left(\mathrm{PO}_{4}-\mathrm{P}\right)$ removal rates. However, the species' natural occurrence in domestic wastewater, in particular, may present an advantage for use in bioremediation of domestic wastewater [40].

\subsection{Algal Growth}

This experiment used a photoperiod of 18:6 h (light:dark) because this is the common photoperiod recorded in Wales during the spring-summer season, and also because this photoperiod sustains growth for longer than consistent, $24 \mathrm{~h}$ light [41]. During the light phase, carbohydrates are accumulated and metabolized for energy, which is then used in protein synthesis during the dark phase [27].

The growth curves (Figure 4) used optical density measurement at $750 \mathrm{~nm}$ as this wavelength reduces absorbance by the pigment chlorophyll, dominant in C. vulgaris cells. Across all conditions, the initial growth rate was consistently higher than the overall growth rate. This was due to the high level of nutrients and light availability between day 0 and 2 as a result of low cell density $\left(<22\right.$ million cell $\left.\mathrm{mL}^{-1}\right)$, which caused high photosynthetic activity, energy production and protein synthesis for cell division [42]. Nutrients were depleted beyond day 2, as shown for $\mathrm{PO}_{4}-\mathrm{P}$ and $\mathrm{NH}_{4}-\mathrm{N}$ (Figures 6 and 7), resulting in reduced assimilation and lower overall growth rates. Growth rates decreased substantially beyond day 7 (Figure $4 a-c$ ).

Biomass production was within the expected typical yield of $0.3-0.6 \mathrm{~g} \mathrm{~L}^{-1}$ [43] and biomass productivity was high $\left(>0.16 \mathrm{~g} \mathrm{~L}^{-1} \mathrm{~d}^{-1}\right)$ under all conditions. T1 and $\mathrm{T} 2$ exhibited higher biomass productivity $\left(>0.074 \mathrm{~g} \mathrm{~L}^{-1} \mathrm{~d}^{-1}\right)$ of Chlorella than was obtained in a similar study using autoclaved secondary treated wastewater [23] (Table 4). This was due to the lower level of nutrients in the secondary wastewater used by Cho et al. [23], which contained only $10.0 \pm 7.1 \mathrm{mg} \mathrm{L}^{-1}$ and $1.7 \pm 0.3 \mathrm{mg} \mathrm{L}^{-1} \mathrm{NH}_{4}-\mathrm{N}$ and total-P, respectively. In contrast, the biomass production for $\mathrm{T} 1$ was far lower than that obtained for Chlorella sp. cultivated on autoclaved centrate $\left(1.175 \mathrm{~g} \mathrm{~L}^{-1}\right)$ by Li et al. [26] (Table 4). The centrate contained 10-fold more $\mathrm{PO}_{4}-\mathrm{P}$, which is used in protein synthesis, than the primary wastewater used in this study and the experiment was conducted over an additional two days. Cho et al. [23] conducted a preliminary experiment with raw untreated effluent. This showed limited growth of Chlorella sp. due to the presence of unicellular bacteria and protozoa that feed on microalgae. The presence of these microorganisms can also inhibit microalgal growth by limiting light penetration from the water surface or through accumulating vital nutrients required for the growth of algae [23]. This suggests that pre-treatment of wastewater (using microfiltration, for example), was required for the growth of microalgae and subsequent nutrient removal.

Table 4. Summary of results and comparison with previous studies.

\begin{tabular}{|c|c|c|c|c|c|c|c|c|}
\hline Strain & $\begin{array}{c}\text { Culture } \\
\text { Medium/ } \\
\text { Wastewater }\end{array}$ & Pre-Treatment & $\begin{array}{l}\text { Light Intensity } \\
\left(\mu \mathrm{mol} \mathrm{m}^{-2} \mathrm{~s}^{-1}\right)\end{array}$ & $\mu_{1}\left(d^{-1}\right)$ & $\% \mathrm{NH}_{4}-\mathrm{N}$ & $\% \mathrm{PO}_{4}-\mathrm{P}$ & $\begin{array}{l}\text { Biomass } \\
\text { Production } \\
\left(\mathrm{mg} \mathrm{L}^{-1} \text { ) }\right.\end{array}$ & References \\
\hline C. vulgaris & Primary (T1) & $0.2 \mu \mathrm{m}$ filtration & 177 & 0.92 & 94.18 & 97.69 & 0.513 & This work \\
\hline Chlorella sp. & Primary & filtration & 200 & 0.43 & 82.40 & 83.20 & - & Wang et al. [44] \\
\hline Chlorella sp. 227 & Secondary & $0.2 \mu \mathrm{m}$ filtration & 60 & - & 92.00 & 86.00 & - & Cho et al. [23] \\
\hline Chlorella sp. $10 b$ & Centrate & - & 50 & 0.48 & 93.00 & 79.00 & 1.175 & Li et al. [26] \\
\hline C. vulgaris & Secondary & - & 135 & 0.19 & 60.10 & - & - & Ruiz-Marin et al. [35] \\
\hline C. vulgaris & Primary (T2) & - & 177 & 0.39 & 95.22 & 96.63 & 0.527 & This work \\
\hline C. vulgaris & F2P media & - & 177 & 0.71 & - & 89.64 & 0.457 & This work \\
\hline
\end{tabular}

The high levels of initial nutrients imply that the low growth rate in T2 was a result of turbidity due to the presence of colloidal particles and suspended solids $[8,23]$ within the unfiltered wastewater. The presence of these compounds reduced light utilization in photosynthesis, which has been 
investigated by previous studies [21,23]. The effect of turbidity on algal growth has not yet been concluded, and a study by Wang [45] had similar mixed findings. However, they suggested that the effect of turbidity, either in inhibiting or stimulating growth, could be related to amount of available nutrients in water. In this case, the high levels of nutrients in T2 stimulated growth regardless of the turbidity of unfiltered wastewater. The presence of additional insoluble organic compounds that can be metabolized directly by algal cells [46], may have contributed to the high biomass production in unfiltered wastewater T2. Microalgae have the capacity to improve the environmental conditions of the growth medium by undergoing self-flocculation in order to increase the light permeability in the system and promote growth. Microalgae cultivation shows a capacity of self-adaptation, which is beneficial to wastewater treatment because the water turbidity can change frequently as rainfall and polluting loads vary daily [47]. The effect of $0.2 \mu \mathrm{m}$ filtration on light availability, through reducing turbidity, may have improved initial growth rates in $\mathrm{T} 1$ due to increased light utilization for photosynthesis compared with T2 (Table 4). This suggestion is supported by the results of Cho et al. [23], who found the highest biomass productivity occurred in membrane filtered $(0.2 \mu \mathrm{m})$ wastewater. However, the present study achieved higher removal efficiencies and higher biomass productivity than Cho et al. [23]. The removal efficiencies obtained by Cho et al. [23] using $0.2 \mu \mathrm{m}$ membrane filtration were only $92 \%$ (T-N) and $86 \%$ (T-P) compared to $94 \%\left(\mathrm{NH}_{4}-\mathrm{N}\right)$ and $97 \%\left(\mathrm{PO}_{4}-\mathrm{P}\right)$ in the present study. This may be due to the use of primary treated wastewater and a higher intensity of illumination, $177 \mu \mathrm{mol} \mathrm{m}^{-2} \mathrm{~s}^{-1}$, in the present study compared with secondary treated wastewater and only $60 \mu \mathrm{mol} \mathrm{m}^{-2} \mathrm{~s}^{-1}$ used by Cho et al. [23] (Table 4).

The control, consisting of F2P media based on the Guillard [48] F/2 medium, had the highest biomass productivity $\left(0.190 \pm 0.048 \mathrm{~g} \mathrm{~L}^{-1} \mathrm{~d}^{-1}\right)$ of all conditions (Table 4$)$. This was an expected result with regard to the growth promoting vitamins [49] presented in F2P, such as thiamine, biotin and cyanocobalamin [50], which were absent from wastewater. However, F2P media consisted of nitrate as the predominant $\mathrm{N}$ source and therefore exhibited a lower initial growth rate $\left(0.710 \pm 0.034 \mathrm{~d}^{-1}\right)$ compared to T1 $\left(0.920 \pm 0.050 \mathrm{~d}^{-1}\right)$ due to the slower assimilation of nitrate compared with ammonium, which was the predominant $\mathrm{N}$ source of domestic wastewater [51,52].

\subsection{Effect of Wastewater Composition on Nutrient Removal}

Freshwater microalgae have been shown to adjust their internal N:P ratio to suit their environment and optimize nutrient uptake and assimilation [42]. This adaptation allows them to exploit the nutrient source provided by wastewater as shown in the high growth rates and biomass production obtained in this study. The optimal inorganic N:P ratio is suggested to be within an ideal range of between 6.8-10 for freshwater algal growth [53-55]. Conditions within this study represented N limitation due to the $<13 \mathrm{~N}: \mathrm{P}$ ratio [56]. The optimal inorganic N:P ratio reflects a more widely accepted phytoplankton stoichiometry, the Redfield ratio (106:16:1), which is the average internal composition of C:N:P [57]. The results of this study were found to support the high growth rate and nutrient removal expected from wastewater composition, closely matching the Redfield ratio $[33,58]$. T1 had an $\mathrm{N}: \mathrm{P}$ ratio of 7.5:1.0 and exhibited the highest removal efficiency across all conditions $\left(97.69 \% \mathrm{PO}_{4}-\mathrm{P}\right)$. $\mathrm{T} 1$ also resulted in higher nutrient removal efficiency of $\mathrm{NH}_{4}-\mathrm{N}(94.18 \%)$ compared to another study. Wang et al. [44] showed removal of only $82.4 \%\left(\mathrm{NH}_{4}-\mathrm{N}\right)$ and $83.2 \%\left(\mathrm{PO}_{4}-\mathrm{P}\right)$ from primary wastewater with a less optimal N:P ratio of 5.9:1.0 (Table 4). Biomass was produced as a result of nutrient uptake and assimilation [59-61]. As $\mathrm{NH}_{4}-\mathrm{N}$ regulates lipid content [62], $\mathrm{N}$ limitation may have resulted in accumulation of storage lipids within $C$. vulgaris due to the low N:P ratio. Storage lipids are metabolized to release energy under cellular stress $[63,64]$. Previous work has found microalgae to enhance the secretion of metabolites when cultivated under nitrogen starvation [65]. These additional metabolites contribute to the accumulation of organic matter within the growth medium and have the potential to increase BOD in wastewater effluent. It is, therefore, important to monitor BOD in order to ascertain the optimal level of $\mathrm{N}$ limitation with low extracellular organic matter (EOM) [66]. Methods such as cell immobilization have been shown to increase nutrient removal further. Ruiz-Marin et al. [35] 
reported only $60.1 \%$ removal of $\mathrm{NH}_{4}-\mathrm{N}$ from secondary wastewater by free $\mathrm{C}$. vulgaris cells compared to removal of $80.0 \%$ by cells immobilized in alginate beads (Table 4 ).

The lower $\mathrm{PO}_{4}$-P removal efficiency of T2 (96.63\%) compared to T1 (97.69\%) (Table 4) may be due to the lower N:P ratio of $\mathrm{T} 2 . \mathrm{N}$ is the limiting factor in $\mathrm{P}$ accumulation because $\mathrm{N}$ is required in protein synthesis, such as of ribosomal RNA, which incorporates P [33,42]. In the case of N limitation, uptake can still occur through a luxury uptake pathway where polyphosphates accumulate within $C$. vulgaris cells, which hydrolyse these to $\mathrm{PO}_{4}-\mathrm{P}$ [67]. This described effect of $\mathrm{N}$ limitation on $\mathrm{P}$ removal was observed in a study conducted by Li et al. [26] using a mixture of Chlorella sp. cultivated by batch culture. Li et al. [26] found a removal efficiency of only $79 \%$ T-P compared to $93 \% \mathrm{NH}_{4}-\mathrm{N}$ using autoclaved centrate with an N:P ratio of 1.0:2.1, clearly presenting $\mathrm{N}$ limitation.

The composition of wastewater in $\mathrm{T} 1$ was most suitable for bioremediation by $\mathrm{C}$. vulgaris as this produced the highest initial growth rate and high nutrient removal efficiency of both $\mathrm{NH}_{4}-\mathrm{N}$ and $\mathrm{PO}_{4}-\mathrm{P}$, comparable to those reported in the literature. Unfiltered wastewater could present a challenge to bioremediation by microalgae when nutrient inputs are low due to the effect of turbidity on light utilization. Previous studies have demonstrated the effect of turbidity on microalgal growth and suggest that phycoremediation techniques should be applied to the wastewater treatment cycle following secondary treatment and settling as water presents more optimal growing conditions in low turbidity [47]. Therefore, with the obtained results and previous research into the application of microalgal bioremediation, it is highly advisable to incorporate a microfiltration step in the wastewater treatment process following secondary treatment, as effluent remains high in inorganic nutrients and has low turbidity. This will achieve high nutrient removal efficiencies.

\subsection{Mechanisms of Nutrient Removal}

The focus of this study was the bioremediation of nitrogen in the form of $\mathrm{NH}_{4}-\mathrm{N}$ and phosphorus in the form of $\mathrm{PO}_{4}-\mathrm{P}$, as the two main nutrients of concern with regard to eutrophication. The removal of one nutrient depended on the availability of another, as both are required for biomass production [42] hence the variety in removal efficiencies as shown in Table 2.

\subsubsection{Nitrogen}

Organic $\mathrm{N}$ is derived from inorganic sources including nitrate, nitrite and ammonium, which are converted from inorganic to organic form through assimilation by $\mathrm{C}$. vulgaris. Inorganic $\mathrm{N}$ was translocated across the plasma membrane where it was reduced from nitrate to nitrite and nitrite to $\mathrm{NH}_{4}-\mathrm{N}$ by nitrite reductase and ferrodoxin [61]. $\mathrm{NH}_{4}-\mathrm{N}$ was incorporated into amino acid (glutamine) by glutamine synthase, requiring glutamate and adenosine triphosphate (ATP), for assimilation to peptides, proteins, enzymes and genetic material [33,61].

$\mathrm{NH}_{4}-\mathrm{N}$ was readily assimilated by $\mathrm{C}$. vulgaris as it does not require as much energy as other forms of inorganic $\mathrm{N}$ such as nitrate [52]. Therefore, nitrate removal does not occur until the majority of $\mathrm{NH}_{4}-\mathrm{N}$ has been consumed $[60,68]$ so wastewaters such as those used in this study, containing high ammonium concentrations, lead to rapid growth of $C$. vulgaris and rapid $\mathrm{NH}_{4}-\mathrm{N}$ uptake, which is a key step in wastewater bioremediation.

\subsubsection{Ammonium}

C. vulgaris growth was accompanied by a decrease in $\mathrm{NH}_{4}-\mathrm{N}$ content of the wastewater due to assimilation of $\mathrm{NH}_{4}-\mathrm{N}$ for biomass production. $\mathrm{NH}_{4}-\mathrm{N}$ is considered the favoured form of inorganic $\mathrm{N}$ over nitrate, which may be the reason for the higher initial growth rate in Treatment 1 than the Control (nitrate in F2P media). The differences in growth of $C$. vulgaris between Treatments 1 and 2 could be attributed to the composition of other simple organic $\mathrm{N}$ sources such as urea and amino acids, likely to be present in large quantity within domestic wastewater [26]. Additional analysis of the depletion of these organic compounds may have provided better insight into the growth of $C$. vulgaris and possible interactions with removal of the target nutrients, $\mathrm{NH}_{4}-\mathrm{N}$ and $\mathrm{PO}_{4}-\mathrm{P}$. 


\subsubsection{Phosphorous}

Organic $P$ is found in nucleic acids, lipids and proteins and plays a vital role in growth and metabolism through its presence in energy transfer compounds such as ATP $[61,69,70]$. Inorganic $P$ such as $\mathrm{PO}_{4}-\mathrm{P}$ present in the form of $\mathrm{H}_{2} \mathrm{PO}_{4}{ }^{-}$was removed from wastewater by photophosphorylation that occurs within chloroplasts of the chlorophyll present in C. vulgaris, producing ATP [71,72].

\subsubsection{Ortho-phosphate}

The removal of $\mathrm{PO}_{4}-\mathrm{P}$ between day 0 and 2 in $\mathrm{T} 1$ (Figure $6 \mathrm{~b}$ ) seemed to occur at a higher rate than in T2 (Figure 6c). This could be due to either the lower ratio of N:P or the effect of turbidity on growth in T2. This observation is supported by the higher initial growth rate between days 0 and 2 in $\mathrm{T} 1$ (Figure $4 \mathrm{~b}$ ) than T2 (Figure 4c).

The decline in $\mathrm{PO}_{4}$-P below $0.42 \mathrm{mg} \mathrm{L}^{-1}$ by day 8 in $\mathrm{T} 1$ presents significant difference to $\mathrm{T} 2$, which remained above this concentration of $\mathrm{PO}_{4}-\mathrm{P}$ throughout the 12-day growth period. This could explain the lack of death phase in the growth curve for T2 (Figure $5 \mathrm{c}$ ), where high growth rates occurred as a result of the elevated levels of $\mathrm{PO}_{4}-\mathrm{P}\left(>0.51 \mathrm{mg} \mathrm{L}^{-1}\right)$ beyond day 8 . The presence of $\mathrm{PO}_{4}-\mathrm{P}$ is likely to be the predominant reason for further growth as $\mathrm{NH}_{4}-\mathrm{N}$ is depleted to $<5 \mathrm{mg} \mathrm{L}^{-1}$ by day 8 in all conditions.

Both $\mathrm{PO}_{4}-\mathrm{P}$ and $\mathrm{NH}_{4}-\mathrm{N}$ decreased rapidly in the first 3 days due to fast assimilation by $\mathrm{C}$. vulgaris. The same was observed in a similar study using tertiary-treated wastewater [29].

\subsection{Microalgal Uses and Current Technologies}

The ability of microalgae to remediate polluting nutrients from wastewater presents an opportunity to reduce the economic and environmental cost of tertiary wastewater treatment whilst improving the quality of final effluent in line with environmental standards (Table 3). Semi-continuous culture can be used for continual removal of nutrients from wastewater by maintaining microalgae in an exponential growth phase [73]. Microalgae can be harvested using a number of methods including centrifugation, sedimentation and flocculation [61]. In certain species of microalgae, the biomass produced by simultaneous bioremediation can itself be applied on land as organic fertilizer either in its raw or semi-decomposed form [74]. This attribute represents the possibility to use microalgae in developing a circular economy [75]. Membrane filtration is also used extensively as a dewatering step in microalgae downstream processing. However, this method could impose a challenge when used in wastewater, as the filter may not separate only microalgal cells from effluent-suspended solids may also accumulate depending on the pore size. This would require maintenance (including chemical cleaning and backwash) and possibly frequent membrane replacements, at a financial cost.

There is some potential for microalgae as feedstock for biofuel metabolites such as lipids and carbohydrates used in the production of biodiesel [76] and other high-value bioactive compounds $[77,78]$. This could provide solutions to the twin challenges of energy security and environmental pollution [75]. However, as microalgal production requires a large cultivation area and additional energy for harvesting and extraction, the prospects are limited [79]. Research and development (R\&D) is needed to develop novel cultivation systems that tackle these issues [79]. Currently, the largest use of the Generally Recognized as Safe (GRAS) Chlorella is in human nutritional supplements and food colourings due to antimicrobial $[80,81]$ and antioxidant $[82,83]$ properties. In addition to its use in human nutrition, it plays an important role in the aquaculture industry, unsurprisingly so, as microalgae form a natural food source in freshwater and marine systems $[62,84,85]$.

\section{Conclusions}

The results of this study demonstrate that $C$. vulgaris is well adapted to growth in domestic wastewater and showed high (>95\%) removal of $\mathrm{NH}_{4}-\mathrm{N}$ and $\mathrm{PO}_{4}-\mathrm{P}$ from primary filtered wastewater. 
Although the final effluent levels were classified as moderate-poor with regard to the concentration of nutrients for discharge into water bodies, these results are promising as they present an improvement on the quality of current domestic wastewater effluent from biological filtration. Bioremediation by C. vulgaris provides one method for improving current wastewater treatment. The use of membrane technology as a part of the wastewater treatment process enhances the nutrient uptake performance of microalgae and the consequent nutrient removal efficiency, as was demonstrated in this study. The results of this work suggest that growing $C$. vulgaris in nutrient-rich filtered wastewater provides an option for domestic wastewater treatment to improve quality of final effluent.

Acknowledgments: The authors would like to acknowledge Dwr Cymru Welsh Water Company for samples, and to allow access to Welsh Water treatment facility in Southgate, Swansea, Wales, United Kingdom.

Author Contributions: Claudio Fuentes-Grünewald and Carole A. Llewellyn conceived and designed the experiments; Elyssia Mayhead performed the experiments; Elyssia Mayhead analyzed the data; Alla Silkina contributed reagents/materials / analysis tools; Elyssia Mayhead, Claudio Fuentes-Grünewald, Alla Silkina and Carole A. Llewellyn wrote the paper.

Conflicts of Interest: The authors declare no conflict of interest.

\section{References}

1. Carpenter, S.R.; Caraco, N.F.; Correll, D.L.; Howarth, R.W.; Sharpley, A.N.; Smith, V.H. Nonpoint pollution of surface waters with phosphorus and nitrogen. Ecol. Appl. 1998, 8, 559-568. [CrossRef]

2. UKTI. Water and Treated Water. UK Trade and Investment. Available online: https:// www.gov.uk/government/publications/water-and-treated-water/water-and-treated-water (accesed on 20 December 2016).

3. De la Noue, J.; de Pauw, N. The potential of microalgal biotechnology: A review of production and uses of microalgae. Biotechnol. Adv. 1988, 6, 725-770. [CrossRef]

4. Smith, V.H. Eutrophication of freshwater and coastal marine ecosystems: A global problem. Environ. Sci. Pollut. Res. Int. 2003, 10, 126-139. [CrossRef] [PubMed]

5. DEFRA. Wastewater Treatment in the United Kingdom; DEFRA: London, UK, 2012; p. 47.

6. Mainston, C.P.; Parr, W. Phosphorus in rivers-Ecology and management. Sci. Total Environ. 2002, $282,25-47$. [CrossRef]

7. UNESCO. Water for a Sustainable World; UNESCO: Paris, France, 2015; p. 126.

8. Abdel-Raouf, N.; Al-Homaidan, A.A.; Ibraheem, I.B.M. Microalgae and wastewater treatment. Saudi J. Biol. Sci. 2012, 19, 257-275. [CrossRef] [PubMed]

9. Gray, N. Biology of Wastewater Treatment, 2nd ed.; Imperial College Press: London, UK, 2004; pp. $26-29$.

10. Carey, R.O.; Migliaccio, K.W. Contribution of wastewater treatment plant effluents to nutrient dynamics in aquatic systems: A review. Environ. Manag. 2009, 44, 205-217. [CrossRef] [PubMed]

11. EEA. Eutrophication in Europe's Coastal Waters; European Environment Agency: Copenhagen, Denmark, $2001 ;$ p. 86.

12. Khan, F.A.; Ansari, A.A. Eutrophication: An ecological vision. Bot. Rev. 2005, 71, 449-482. [CrossRef]

13. Carlisle, S. Productive Filtration: Living System Infrastructure in Calcutta. Available online: http:// scenariojournal.com/article/productive-filtration-living-system-infrastructure-in-calcutta/ (accessed on 20 December 2016).

14. UKTAG. Environmental Standards And Conditions (Phase 2); UK Technical Advisory Group on the Water Framework Directive: London, UK, 2008; p. 84.

15. De la Noüe, J.; Laliberté, G.; Proulx, D. Algae and waste water. J. Appl. Phycol. 1992, 4, 247-254. [CrossRef]

16. Palmer, C. Algae in american sewage stabilization ponds. Rev. Microbiol. (S-Paulo) 1974, 75-80.

17. Przytocka-Jusiak, M.; Duszota, M.; Matusiak, K.; Mycielski, R. Intensive culture of chlorella vulgaris/aa as the second stage of biological purification of nitrogen industry wastewaters. Water Res. 1984, 18, 1-7. [CrossRef]

18. Priyadarshani, I.; Sahu, D.; Rath, B. Microalgal bioremediation: Current practices and perspectives. J. Biochem. Technol. 2011, 3, 299-3004. 
19. Comber, S.D.W.; Gardner, M.J.; Churchley, J. Aluminium speciation: Implications of wastewater effluent dosing on river water quality. Chem. Speciat. Bioavailab. 2005, 17, 117-128. [CrossRef]

20. Zacharof, M.-P.; Lovitt, R.W. Adding value to wastewater by resource recovery and reformulation as growth media: Current prospects and potential. J. Water Reuse Desalination 2015, 5, 473-479. [CrossRef]

21. Silkina, A.; Zacharof, M.-P.; Hery, G.; Nouvel, T.; Lovitt, R.W. Formulation and utilisation of spent anaerobic digestate fluids for the growth and product formation of single cell algal cultures in heterotrophic and autotrophic conditions. Bioresour. Technol. 2017, 244, 1445-1455. [CrossRef] [PubMed]

22. Li, J.; Chase, H.A. Applications of membrane techniques for purification of natural products. Biotechnol. Lett. 2010, 32, 601-608. [CrossRef] [PubMed]

23. Cho, S.; Luong, T.T.; Lee, D.; Oh, Y.K.; Lee, T. Reuse of effluent water from a municipal wastewater treatment plant in microalgae cultivation for biofuel production. Bioresour. Technol. 2011, 102, 8639-8645. [CrossRef] [PubMed]

24. Zacharof, M.-P.; Lovitt, R.W. The filtration characteristics of anaerobic digester effluents employing cross flow ceramic membrane microfiltration for nutrient recovery. Desalination 2014, 341, 27-37. [CrossRef]

25. Henze, M.C.Y. Wastewater characterization. In Biological Wastewater Treatment: Principles, Modelling and Design; Henze, M.v.L., van Loosdrecht, M.C.M., Ekama, G.A., Brdjanovic, D., Eds.; IWA Publishing: London, UK, 2008; pp. 33-52.

26. Li, Y.; Chen, Y.F.; Chen, P.; Min, M.; Zhou, W.; Martinez, B.; Zhu, J.; Ruan, R. Characterization of a microalga Chlorella sp. Well adapted to highly concentrated municipal wastewater for nutrient removal and biodiesel production. Bioresour. Technol. 2011, 102, 5138-5144. [CrossRef] [PubMed]

27. Sharma, R.S.; Singh, G.P.; Sharma, V.K. Effects of culture conditions on growth and biochemical profile of Chlorella vulgaris. J. Plant Pathol. Microb. 2012, 3, doi.org/10.4172/2157-747110001. [CrossRef]

28. Dickinson, K.E.; Whitney, C.G.; McGinn, P.J. Nutrient remediation rates in municipal wastewater and their effect on biochemical composition of the microalga Scenedesmus sp. AMDD. Algal Res. 2013, 2, 127-134. [CrossRef]

29. Ji, M.-K.; Abou-Shanab, R.A.I.; Kim, S.-H.; Salama, E.-S.; Lee, S.-H.; Kabra, A.N.; Lee, Y.-S.; Hong, S.; Jeon, B.-H. Cultivation of microalgae species in tertiary municipal wastewater supplemented with $\mathrm{CO}_{2}$ for nutrient removal and biomass production. Ecol. Eng. 2013, 58, 142-148. [CrossRef]

30. Stein, J.R. Handbook of Phycological Methods: Culture Methods and Growth Measurements; Cambridge University Press Archive: Cambridge, UK, 1973; Volume 1, p. 265.

31. Feng, Y.; Li, C.; Zhang, D. Lipid production of Chlorella vulgaris cultured in artificial wastewater medium. Bioresour. Technol. 2011, 102, 101-105. [CrossRef] [PubMed]

32. Griffiths, M.J.; Garcin, C.; van Hille, R.P.; Harrison, S.T. Interference by pigment in the estimation of microalgal biomass concentration by optical density. J. Microbiol. Methods 2011, 85, 119-123. [CrossRef] [PubMed]

33. Whitton, R.; Le Mével, A.; Pidou, M.; Ometto, F.; Villa, R.; Jefferson, B. Influence of microalgal n and $\mathrm{p}$ composition on wastewater nutrient remediation. Water Res. 2016, 91, 371-378. [CrossRef] [PubMed]

34. De-Bashan, L.E.; Moreno, M.; Hernandez, J.-P.; Bashan, Y. Removal of ammonium and phosphorus ions from synthetic wastewater by the microalgae Chlorella vulgaris coimmobilized in alginate beads with the microalgae growth-promoting bacterium azospirillum brasilense. Water Res. 2002, 36, 2941-2948. [CrossRef]

35. Ruiz-Marin, A.; Mendoza-Espinosa, L.G.; Stephenson, T. Growth and nutrient removal in free and immobilized green algae in batch and semi-continuous cultures treating real wastewater. Bioresour. Technol. 2010, 101, 58-64. [CrossRef] [PubMed]

36. Lananan, F.; Jusoh, A.; Ali, N.a.; Lam, S.S.; Endut, A. Effect of conway medium and f/2 medium on the growth of six genera of south china sea marine microalgae. Bioresour. Technol. 2013, 141, 75-82. [CrossRef] [PubMed]

37. Valderrama, L.T.; Del Campo, C.M.; Rodriguez, C.M.; de- Bashan, L.E.; Bashan, Y. Treatment of recalcitrant wastewater from ethanol and citric acid production using the microalga Chlorella vulgaris and the macrophyte Lemna minuscula. Water Res. 2002, 36, 4185-4192. [CrossRef]

38. Lim, S.-L.; Chu, W.-L.; Phang, S.-M. Use of chlorella vulgaris for bioremediation of textile wastewater. Bioresour. Technol. 2010, 101, 7314-7322. [CrossRef] [PubMed]

39. Riaño, B.; Molinuevo, B.; García-González, M.C. Treatment of fish processing wastewater with microalgae-containing microbiota. Bioresour. Technol. 2011, 102, 10829-10833. [CrossRef] [PubMed] 
40. Pipes, W.O.; Gotaas, H.B. Utilization of organic matter by chlorella grown in sewage. Appl. Microbiol. 1960, 8 , 163-169. [PubMed]

41. Bouterfas, R.B.M.; Dauta, A. The effects of irradiance and photoperiod on the growth rate of three freshwater green algae isolated from a eutrophic lake. Limnetica 2006, 25, 647-656.

42. Beuckels, A.; Smolders, E.; Muylaert, K. Nitrogen availability influences phosphorus removal in microalgae-based wastewater treatment. Water Res. 2015, 77, 98-106. [CrossRef] [PubMed]

43. Sydney, E.B.; da Silva, T.E.; Tokarski, A.; Novak, A.C.; de Carvalho, J.C.; Woiciecohwski, A.L.; Larroche, C.; Soccol, C.R. Screening of microalgae with potential for biodiesel production and nutrient removal from treated domestic sewage. Appl. Energy 2011, 88, 3291-3294. [CrossRef]

44. Wang, L.; Min, M.; Li, Y.; Chen, P.; Chen, Y.; Liu, Y.; Wang, Y.; Ruan, R. Cultivation of green algae Chlorella sp. In different wastewaters from municipal wastewater treatment plant. Appl. Biochem. Biotechnol. 2010, 162, 1174-1186. [CrossRef] [PubMed]

45. Wang, W. Effect of Turbidity on Algal Growth; Illinois State Water Survey: Champaign, IL, USA, 1974.

46. Myers, J. Physiology of the algae. Ann. Rev. Microb. 1951, 5, 157-180. [CrossRef] [PubMed]

47. Iasimone, F.; De Felice, V.; Panico, A.; Pirozzi, F. Experimental study for the reduction of $\mathrm{CO}_{2}$ emissions in wastewater treatment plant using microalgal cultivation. J. $\mathrm{CO}_{2}$ Utili. 2017, 22, 1-8. [CrossRef]

48. Guillard, R.R.L. Culture of phytoplankton for feeding marine invertebrates. In Culture of Marine Invertebrate Animals: Proceedings-1st Conference on Culture of Marine Invertebrate Animals Greenport; Smith, W.L., Chanley, M.H., Eds.; Springer: Boston, MA, USA, 1975; pp. 29-60.

49. Croft, M.T.; Warren, M.J.; Smith, A.G. Algae need their vitamins. Eukaryot. Cell 2006, 5, 1175-1183. [CrossRef] [PubMed]

50. CCAP. F/2 Medium. Available online: www.Ccap.Ac.Uk/media/documents/f2 (accesed on 6 February 2017).

51. Hammouda, O.; Gaber, A.; Abdel-Raouf, N. Microalgae and wastewater treatment. Ecotoxicol. Environ. Saf. 1995, 31, 205-210. [CrossRef] [PubMed]

52. Perez-Garcia, O.; Escalante, F.M.E.; de-Bashan, L.E.; Bashan, Y. Heterotrophic cultures of microalgae: Metabolism and potential products. Water Res. 2011, 45, 11-36. [CrossRef] [PubMed]

53. Darley, W. Algal Biology: A Physiological Approach; Basic Microbiology: Oxford, UK, 1982.

54. Reynolds, C. The Ecology of Freshwater Phytoplankton; Cambridge University Press: Cambridge, UK, 1984.

55. Martin, C.; De la Noüe, J.; Picard, G. Intensive cultivation of freshwater microalgae on aerated pig manure. Biomass 1985, 7, 245-259. [CrossRef]

56. Hillebrand, H.; Sommer, U. The nutrient stoichiometry of benthic microalgal growth: Redfield proportions are optimal. Limnol. Oceanogr. 1999, 44, 440-446. [CrossRef]

57. Redfield, A.C. On the Proportions of Organic Derivatives in Sea Water and Their Relation to the Composition of Plankton; University Press of Liverpool: Liverpool, UK, 1934.

58. Choi, H.J.; Lee, S.M. Effect of the N/P ratio on biomass productivity and nutrient removal from municipal wastewater. Bioproc. Biosyst. Eng. 2015, 38, 761-766. [CrossRef] [PubMed]

59. Tam, N.F.Y.; Wong, Y.S. Effect of ammonia concentrations on growth of Chlorella vulgaris and nitrogen removal from media. Bioresour. Technol. 1996, 57, 45-50. [CrossRef]

60. Gerardo, M.L.; Van Den Hende, S.; Vervaeren, H.; Coward, T.; Skill, S.C. Harvesting of microalgae within a biorefinery approach: A review of the developments and case studies from pilot-plants. Algal Res. 2015, 11, 248-262. [CrossRef]

61. Cai, T.; Park, S.Y.; Li, Y.B. Nutrient recovery from wastewater streams by microalgae: Status and prospects. Renew. Sustain. Energy Rev. 2013, 19, 360-369. [CrossRef]

62. Becker, E. Microalgae: Biotechnology and Microbiolog; Cambridge University Press: Cambridge, UK, 1994.

63. Rodolfi, L.; Chini Zittelli, G.; Bassi, N.; Padovani, G.; Biondi, N.; Bonini, G.; Tredici, M.R. Microalgae for oil: Strain selection, induction of lipid synthesis and outdoor mass cultivation in a low-cost photobioreactor. Biotechnol. Bioeng. 2009, 102, 100-112. [CrossRef] [PubMed]

64. Widjaja, A.; Chien, C.C.; Ju, Y.H. Study of increasing lipid production from fresh water microalgae Chlorella vulgaris. J. Taiwan Inst. Chem. Eng. 2009, 40, 13-20. [CrossRef]

65. Espen, G.; Stãle, K.; Sverre, M.M. Cellular and extracellular production of carbohydrates and amino acids by the marine diatom skeletonema costatum: Diel variations and effects of $\mathrm{N}$ depletion. Marine Ecol. Prog. Ser. 2002, 242, 83-94. 
66. Wang, Y.; Guo, W.; Yen, H.-W.; Ho, S.-H.; Lo, Y.-C.; Cheng, C.-L.; Ren, N.; Chang, J.-S. Cultivation of Chlorella vulgaris JSC-6 with swine wastewater for simultaneous nutrient/COD removal and carbohydrate production. Bioresour. Technol. 2015, 198, 619-625. [CrossRef] [PubMed]

67. Pick, U.; Rental, M.; Chitlaru, E.; Weiss, M. Polyphosphate-hydrolysis-A protective mechanism against alkaline stress? Febs. Lett. 1990, 274, 15-18. [PubMed]

68. Maestrini, S.Y.; Robert, J.M.; Leftley, J.W.; Collos, Y. Ammonium thresholds for simultaneous uptake of ammonium and nitrate by oyster-pond algae. J. Exp. Mar. Biol. Ecol. 1986, 102, 75-98. [CrossRef]

69. Richmond, A. Handbook of Microalgal Culture: Biotechnology and Applied Phycology; Blackwell Science Ltd.: Oxford, UK, 2004.

70. Chen, M.; Tang, H.; Ma, H.; Holland, T.C.; Ng, K.Y.S.; Salley, S.O. Effect of nutrients on growth and lipid accumulation in the green algae dunaliella tertiolecta. Bioresour. Technol. 2011, 102, 1649-1655. [CrossRef] [PubMed]

71. Emerson, R.L.; Stauffer, J.F.; Umbreit, W.W. Relationships between phosphorylation and photosynthesis in chlorella. Am. J. Bot. 1944, 31, 107-120. [CrossRef]

72. Yang, C.; Hua, Q.; Shimizu, K. Energetics and carbon metabolism during growth of microalgal cells under photoautotrophic, mixotrophic and cyclic light-autotrophic/dark-heterotrophic conditions. Biochem. Eng. J. 2000, 6, 87-102. [CrossRef]

73. Zhu, L.; Wang, Z.; Shu, Q.; Takala, J.; Hiltunen, E.; Feng, P.; Yuan, Z. Nutrient removal and biodiesel production by integration of freshwater algae cultivation with piggery wastewater treatment. Water Res. 2013, 47, 4294-4302. [CrossRef] [PubMed]

74. Riesing, T. Cultivating algae for liquid fuel production. Permac. Activist 2006, 48, 59.

75. Venkata Mohan, S.; Nikhil, G.N.; Chiranjeevi, P.; Nagendranatha Reddy, C.; Rohit, M.V.; Kumar, A.N.; Sarkar, O. Waste biorefinery models towards sustainable circular bioeconomy: Critical review and future perspectives. Bioresour. Technol. 2016, 215, 2-12. [CrossRef] [PubMed]

76. Cabanelas, I.T.D.; Ruiz, J.; Arbib, Z.; Chinalia, F.A.; Garrido-Pérez, C.; Rogalla, F.; Nascimento, I.A.; Perales, J.A. Comparing the use of different domestic wastewaters for coupling microalgal production and nutrient removal. Bioresour. Technol. 2013, 131, 429-436. [CrossRef] [PubMed]

77. Borowitzka, M.A. Microalgae as sources of pharmaceuticals and other biologically active compounds. J. Appl. Phycol. 1995, 7, 3-15. [CrossRef]

78. Fuentes-Grünewald, C.; Bayliss, C.; Zanain, M.; Pooley, C.; Scolamacchia, M.; Silkina, A. Evaluation of batch and semi-continuous culture of porphyridium purpureum in a photobioreactor in high latitudes using fourier transform infrared spectroscopy for monitoring biomass composition and metabolites production. Bioresour. Technol. 2015, 189, 357-363. [CrossRef] [PubMed]

79. Chiu, S.-Y.; Kao, C.-Y.; Chen, T.-Y.; Chang, Y.-B.; Kuo, C.-M.; Lin, C.-S. Cultivation of microalgal chlorella for biomass and lipid production using wastewater as nutrient resource. Bioresour. Technol. 2015, 184, 179-189. [CrossRef] [PubMed]

80. Pratt, R.; Daniels, T.C.; Eiler, J.J.; Gunnison, J.B.; Kumler, W.D.; Oneto, J.F.; Strait, L.A.; Spoehr, H.A.; Hardin, G.J.; Milner, H.W.; et al. Chlorellin, an antibacterial substance from chlorella. Science 1944, 99, 351-352. [CrossRef] [PubMed]

81. Ördög, V.; Stirk, W.A.; Lenobel, R.; Bancířová, M.; Strnad, M.; van Staden, J.; Szigeti, J.; Németh, L. Screening microalgae for some potentially useful agricultural and pharmaceutical secondary metabolites. J. Appl. Phycol. 2004, 16, 309-314. [CrossRef]

82. Suarez, E.R.; Kralovec, J.A.; Noseda, M.D.; Ewart, H.S.; Barrow, C.J.; Lumsden, M.D.; Grindley, T.B. Isolation, characterization and structural determination of a unique type of arabinogalactan from an immunostimulatory extract of chlorella pyrenoidosa. Carbohydr. Res. 2005, 340, 1489-1498. [CrossRef] [PubMed]

83. Suarez, E.R.; Syvitski, R.; Kralovec, J.A.; Noseda, M.D.; Barrow, C.J.; Ewart, H.S.; Lumsden, M.D.; Grindley, T.B. Immunostimulatory polysaccharides from chlorella pyrenoidosa. A new galactofuranan. Measurement of molecular weight and molecular weight dispersion by dosy NMR. Biomacromolecules 2006, 7, 2368-2376. [CrossRef] [PubMed] 
84. Muller-Feuga, A. Microalgae for aquaculture. The current global situation and future trends. In Handbook of Microalgal Culture; Blackwell Science Ltd.: Oxford, UK, 2004; pp. 352-364.

85. Spolaore, P.; Joannis-Cassan, C.; Duran, E.; Isambert, A. Commercial applications of microalgae. J. Biosci. Bioeng. 2006, 101, 87-96. [CrossRef] [PubMed] 